\title{
Correlation of morphological parameters of donkey
} from Austria

\author{
M. Uroševič́, D. Drobnjak, R. Vlaeva, G. Stanišić, R. Mandić, N. Grittner \\ and P. Dameski
}

\begin{abstract}
The donkey, as a work animal, is gradually losing its value. Agriculture industrialization, mechanization of many processes on mountain and valley farms have lead to a reduction of donkey livestock. This reduction gives cause for concern, and is good reason to study all aspects of these domestic animals in order to revive its role, to restart livestock growth in its familiar habitats, and to introduce it into new environments. This study focuses on these aspects. The domestic donkey (Equus asinus) originated from Africa, and there are two kinds of African donkeys: Nubian and Somali. Their enormous, almost mystical, endurance is well known. There is no place in the world where a donkey is not able to perform the most difficult work, above all in transporting goods. A donkey has an amazing capability of stable movement through the most difficult places. For study sample consisted of 44 donkeys (28 males and 16 females) from Austria. The following morphometric parameters were analysed: height at the withers, height at the back, height of the croup, body length, chest depth, chest width, chest circumference anterior, chest circumference posterior, shin circumference,
\end{abstract}

head length, skull length, face length, skull width, face width, length of ears. Measurements were performed using a ruler, tape measure and vernier callipers. The average height at the withers of males was $116.40 \mathrm{~cm}$, ranging from 99.60 to $140.60 \mathrm{~cm}$, while for females, the average was $102.38 \mathrm{~cm}$, ranging from 90.50 to $125.70 \mathrm{~cm}$. Body length of males was on average $121.85 \mathrm{~cm}$ with a standard deviation of 11.79 , while the mean body length for females is $115.80 \mathrm{~cm}$, with a range of 101.00 to $131.00 \mathrm{~cm}$. Male head length ranged from 48.00 to $71.00 \mathrm{~cm}$, with an average of $55.60 \mathrm{~cm}$, while in females, head length was on average $50.06 \mathrm{~cm}$, ranging from 43.00 to $56.00 \mathrm{~cm}$. Using the Pearson correlation, a very significant or significant positive statistical correlation was observed between almost all parameters of males, while for females, Pearson correlation values had slightly different values than for males. There was no statistically significant correlation between chest width and anterior chest circumference with nearly any other parameters. For females, a negative correlation between the skull width and all other parameters was also observed.

Key words: donkey; morphometry; correlation

Milivoje UROŠEVIĆ* ${ }^{*}$ DVM, MVM, PhD, (Corresponding author: e-mail: milivoje.urosevic@gmail.com), Darko DROBNJAK, DVM, MSc, Center for Preservation of Indigenous Breeds, Belgrade, Serbia; Radka VLAEVA, PhD, Head of the Department of Horse Breeding Thracian University - Stara Zagora, Bulgaria, Goran STANIŠIĆ, Professor, PhD, High Agricultural School of Vocational Studies, Šabac, Serbia; Radomir MANDIĆ, PhD, Assistant Professor, Faculty of Ecology Futura, University Metropolitan, Belgrade, Serbia; Natalija GRITTNER, MSc, Center for Preservation of Indigenous Breeds, Belgrade, Serbia, Panče DAMESKI, DVM, PhD, Assistant Professor, Faculty of Veterinary Medicine Bitola, University "St. Kliment Ohridski", Republic of North Macedonia 


\section{Introduction}

The donkey, as a labour animal, is gradually losing its value. Agriculture industrialization, mechanization of many processes on mountain and valley farms have led to reductions in donkey livestock, which is cause for concern. This is good reason to study all the aspects of these domestic animals in order to revive their role, to restart its livestock growth in familiar habitats, and to introduce them into new environments. This study focuses on the aspects above.

The domestic donkey (Equus asinus) comes from Africa, and there are two kinds of African donkeys: Nubian and Somali. Their enormous, almost mystical endurance, is well known. There is no place in the world where a donkey is not able to perform the most difficult work, above all in the transportation of goods. The donkey has an amazing capability of stable movement through the most difficult places.

To date, examination of exterior traits has been performed on multiple populations in several countries. In Italy, the basic morphological parameters of the Amiata donkey breed in Tuscany province were (Orlandi et al., 1997; Casini et al., 2007). There is also research on the morphological characteristics of donkeys in the Turkish region of Igdir (Yilmaz and Ertugrul, 2011). On the Adriatic islands, the donkey was a basic working animal. The morphological characteristics of donkeys on the island of Mljet were studied almost 60 years ago (Essert, 1959). The Baroque donkey is one of the rarest donkey races in the world. The first study on the morphological characteristics of this breed was published in 2019 (Urosevic et al., 2019). The external characteristics of donkeys in the Kabylie area of Algeria are reported in a 2019 study (Ayad et al., 2019). Ebangi and Vall (2005) report the basic morphological parameters of donkeys in Cameroon, in the Sudan-Sahel region. Donkey body conformation tests were also performed in northwestern and central Ethiopia (Tsega and Lemma, 2015). In Turkey, studies were conducted on several donkey populations. The populations in western Turkey (Urosevic et al., 2016), and in southern and southeastern Turkey (Yilmaz and Trevor Wilson, 2013) have been examined. The structure of the Primorsko-Dinaric donkey has been well researched in Croatia (Ivanković et al., 2000).

The morphometric characteristics of donkeys in northwestern Nigeria were studied by John et al. (2017). In Spain, the population of Catalan donkeys was examined (Polch and Jordana, 1997). Đermanović et al. (2013) studied the morphometry of young donkeys, up to two years old, in southern Serbia. The exterior traits of domestic donkey in southeastern Serbia were reported by Trailović et al. (2011). Extensive research has been done by Vlaeva et al. (2016) on the morphological traits of donkeys in Bulgaria. The relationship of head length with ridge height was studied in Romania, Northern Macedonia and Turkey by Urosevic et al. (2015). The morphological characteristics of donkeys in the Czech Republic are reported by Kostukova et al. (2015). The group of great donkeys includes donkeys of the Italian Romagnolo breed, which were studied by Beretti et al. (2005). The morphological features of Hasavi donkeys, an indigenous breed in the eastern province of Saudi Arabia were reported by Shawaf et al. (2016).

\section{Materials and methods}

The study sample consisted of 44 donkeys (28 males and 16 females) from Austria. The following morphometric traits were analysed: height at the withers $(\mathrm{WH})$, height at the back $(\mathrm{BH})$, height of the croup $(\mathrm{CH})$, body length (BL), chest 
depth (CD), chest width (CW), chest circumference anterior (CCA), chest circumference posterior (CCP), shin circumference (SC), head length (HL), skull length (SL), face length (FL), skull width (SW), face width (FW), length of ears (EL). All measurements were performed using a ruler, tape measure and vernier callipers.

The data were first processed by descriptive statistics by gender, and Pearson's correlation method was used to determine the dependence among the measured parameters. The data collected were processed using Statistical Package for the Social Sciences (SPSS) software for Windows Release 17.0.0.

\section{Results}

The results of descriptive statistics for males (Table 1) show that the average height at the withers is $116.40 \mathrm{~cm}$, with a range from 99.60 to $140.60 \mathrm{~cm}$. The back height averages $113.25 \mathrm{~cm}$ with a standard deviation of 11.52. The croup is taller than the height of the withers, with a minimum height of $100.20 \mathrm{~cm}$, and maximum height of $144.10 \mathrm{~cm}$, and an average height of $118.02 \mathrm{~cm}$. The body length of males is on average $121.85 \mathrm{~cm}$ with a standard deviation of 11.79. Chest depth varies from 45.00 to $63.00 \mathrm{~cm}$ with an average value of 51.44 $\mathrm{cm}$, and chest width averages $29.08 \mathrm{~cm}$. The anterior circumference of the chest varies from 106.00 to $161.00 \mathrm{~cm}$, while the posterior circumference of the chest varies from 118.00 to $194.00 \mathrm{~cm}$. The circumference of the shin averages $15.07 \mathrm{~cm}$ with a standard deviation of $1.98 \mathrm{~cm}$. The length of the head is from 48.00 to $71.00 \mathrm{~cm}$, with an average value of $55.60 \mathrm{~cm}$. The mean length of the face is $29.78 \mathrm{~cm}$, and mean length of the cranial part is $25.82 \mathrm{~cm}$. The width of the cranial part is from 21.00 to 26.00 $\mathrm{cm}$, and the width of the face varies from 10.00 to $17.00 \mathrm{~cm}$. The mean length of the ears is $25.96 \mathrm{~cm}$.

In females, the height of the withers varies between 90.50 and $125.70 \mathrm{~cm}$, with an average height of $102.38 \mathrm{~cm}$, with a standard deviation of 8.28 and a standard error of 2.07. The height of the back is

Table 1. Descriptive Statistics - Males

\begin{tabular}{|c|c|c|c|c|c|c|}
\hline \multirow{2}{*}{ Parameter } & $\mathbf{N}$ & Minimum & Maximum & \multicolumn{2}{|c|}{ Mean } & Std. Deviation \\
\cline { 2 - 7 } & & $(\mathbf{c m})$ & $(\mathbf{c m})$ & $(\mathbf{c m})$ & Std. Error & (cm) \\
\hline WH & 28 & 99.60 & 140.60 & 116.40 & 2.22 & 11.75 \\
\hline BH & 28 & 96.40 & 139.50 & 113.25 & 2.18 & 11.53 \\
\hline CH & 28 & 100.20 & 144.10 & 118.02 & 2.28 & 12.08 \\
\hline BL & 28 & 103.00 & 146.00 & 121.85 & 2.23 & 11.80 \\
\hline CD & 27 & 45.00 & 63.00 & 51.44 & 1.03 & 5.35 \\
\hline CW & 27 & 20.00 & 38.70 & 29.08 & 0.99 & 5.13 \\
\hline CCA & 25 & 106.00 & 161.00 & 126.52 & 2.90 & 14.51 \\
\hline CCP & 28 & 118.00 & 194.00 & 147.75 & 3.28 & 17.35 \\
\hline SC & 28 & 12.00 & 20.00 & 15.07 & 0.37 & 1.98 \\
\hline HL & 28 & 48.00 & 71.00 & 55.61 & 1.04 & 5.49 \\
\hline SL & 28 & 23.00 & 30.00 & 25.82 & 0.35 & 1.87 \\
\hline FL & 28 & 23.00 & 42.00 & 29.79 & 0.83 & 4.37 \\
\hline SW & 28 & 21.00 & 26.00 & 22.93 & 0.29 & 1.51 \\
\hline FW & 28 & 10.00 & 17.00 & 13.11 & 0.38 & 1.99 \\
\hline EL & 28 & 20.00 & 31.00 & 25.96 & 0.56 & 2.94 \\
\hline
\end{tabular}


Table 2. Descriptive Statistics - Females

\begin{tabular}{|c|c|c|c|c|c|c|}
\hline \multirow{2}{*}{ Parameter } & $\mathbf{N}$ & Minimum & Maximum & \multicolumn{2}{|c|}{ Mean } & \multicolumn{2}{|c|}{ Std. Deviation } \\
\cline { 2 - 7 } & & $(\mathbf{c m})$ & $(\mathbf{c m})$ & $(\mathbf{c m})$ & Std. Error & (cm) \\
\hline WH & 16 & 90.50 & 125.70 & 102.38 & 2.07 & 8.29 \\
\hline BH & 16 & 91.20 & 121.50 & 99.68 & 1.84 & 7.37 \\
\hline CH & 16 & 94.70 & 128.80 & 106.27 & 1.99 & 7.97 \\
\hline BL & 16 & 101.00 & 131.00 & 115.80 & 2.01 & 8.03 \\
\hline CD & 16 & 41.00 & 59.30 & 47.40 & 1.41 & 5.63 \\
\hline CW & 16 & 20.10 & 40.80 & 28.21 & 1.46 & 5.84 \\
\hline CCA & 16 & 101.00 & 145.00 & 119.94 & 2.92 & 11.68 \\
\hline CCP & 10 & 127.00 & 165.00 & 149.40 & 3.26 & 10.31 \\
\hline SC & 16 & 12.00 & 17.00 & 13.28 & 0.33 & 1.32 \\
\hline HL & 16 & 43.00 & 56.00 & 50.06 & 0.81 & 3.23 \\
\hline SL & 16 & 22.00 & 26.00 & 23.93 & 0.35 & 1.39 \\
\hline FL & 16 & 21.00 & 31.00 & 26.12 & 0.63 & 2.53 \\
\hline SW & 16 & 20.00 & 25.00 & 22.31 & 0.37 & 1.49 \\
\hline FW & 16 & 8.00 & 16.00 & 11.84 & 0.43 & 1.71 \\
\hline EL & 16 & 21.00 & 31.00 & 24.09 & 0.60 & 2.42 \\
\hline
\end{tabular}

$99.68 \mathrm{~cm}$ on average, with a standard deviation of 7.37. The height of the croup in females is from $94.70 \mathrm{~cm}$ to 128.80 $\mathrm{cm}$. Body length is from 101.00 to 131.00 $\mathrm{cm}$, with a mean length of $115.80 \mathrm{~cm}$. The mean chest depth is $47.40 \mathrm{~cm}$, and average width is $28.21 \mathrm{~cm}$. The anterior chest circumference varies from 101.00 to $145.00 \mathrm{~cm}$, and the posterior chest circumference is from 127.00 to 165.00 $\mathrm{cm}$. The mean circumference of the shin is $13.28 \mathrm{~cm}$ with a standard deviation of $1.31 \mathrm{~cm}$. The length of the head in females varies from 43.00 to $56.00 \mathrm{~cm}$, with an average head length of $50.06 \mathrm{~cm}$ and standard deviation of 3.23. The mean length of the cranial part is $23.93 \mathrm{~cm}$, and mean length of the facial part is 26.12 $\mathrm{cm}$. The width of the skull ranges from 20.00 to $25.00 \mathrm{~cm}$, and the width of the facial part ranges from 8.00 to $16.00 \mathrm{~cm}$. The length of ears in females ranges from 21.00 to $31.00 \mathrm{~cm}$.

Using the Pearson correlation, a very significant or significant positive statistical correlation was observed between almost all parameters in males
(Table 3). However, no statistically significant correlation was observed between cranial width and withers height, back height, croup height, body length, chest depth, anterior chest circumference, cranial length of the head, ear length.

For females, Pearson correlation values have slightly different values than for males (Table 4). There was no statistically significant correlation between chest width and anterior chest circumference with other parameters. For chest width and anterior chest circumference, a significant statistical correlation was only observed with body length, anterior and posterior chest circumference, and chest depth. In females, a negative correlation was observed between the width of the cranial part and all other parameters. However, this negative correlation was not statistically significant, except for the ratio of the width of the cranial part and the posterior circumference of the chest. Among all other parameters in females, a very significant or significant statistical value of the positive correlation of the measured parameters was recorded. 


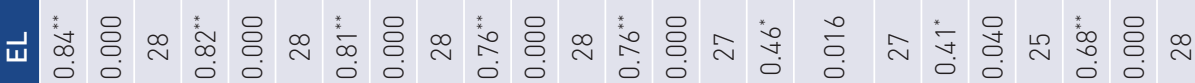

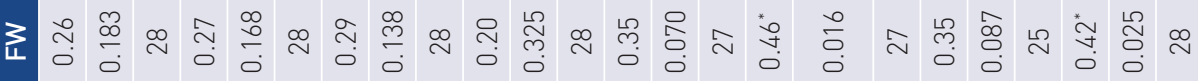

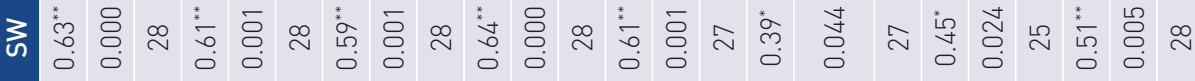

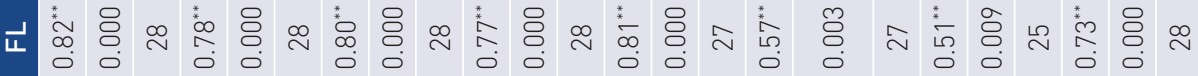

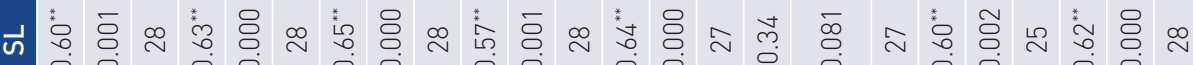

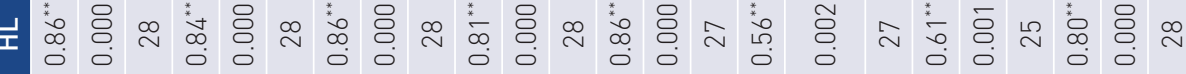
U 엉

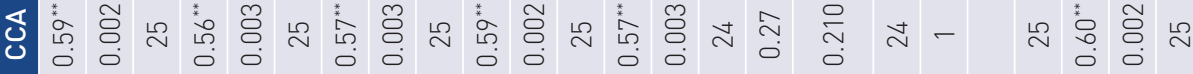
孔

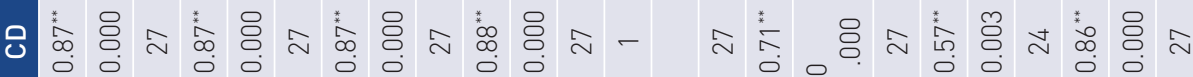

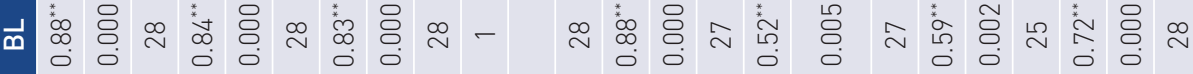
工

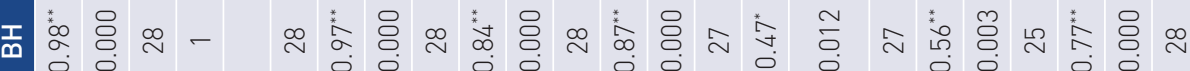

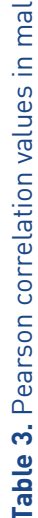

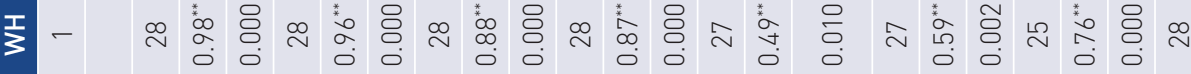

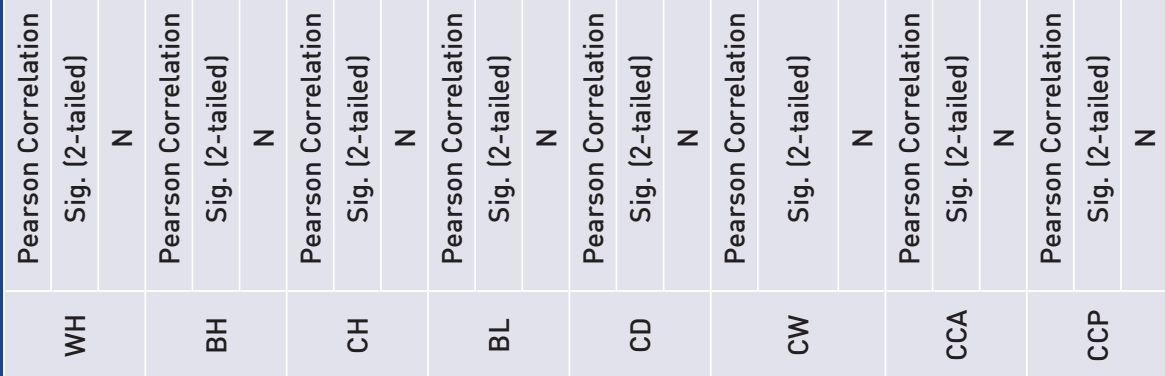




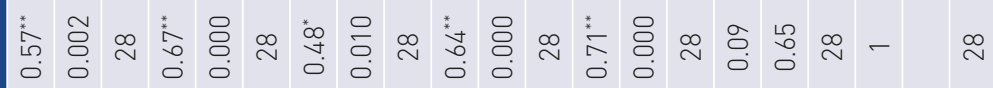

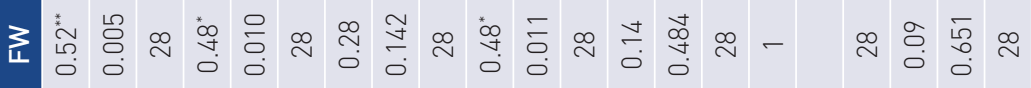

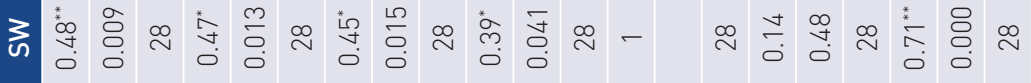

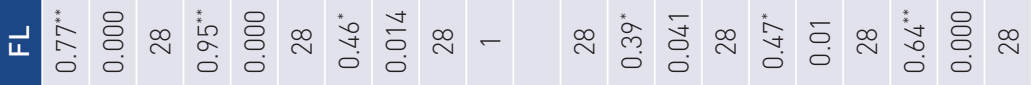

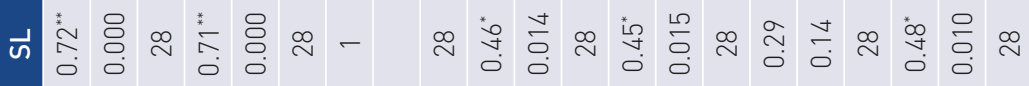

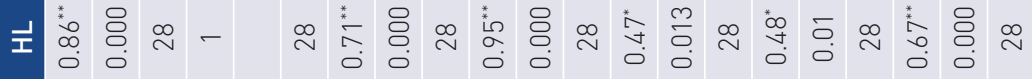

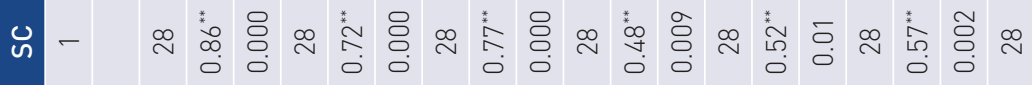

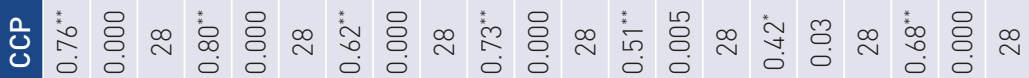

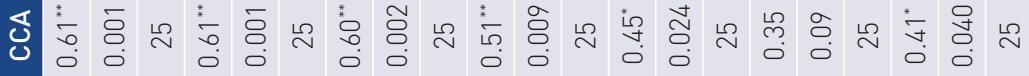

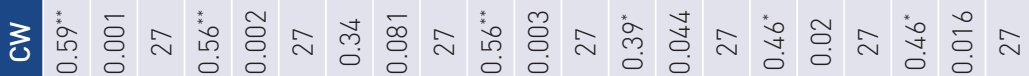

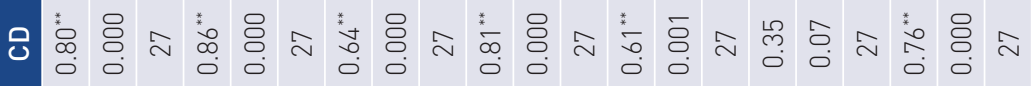

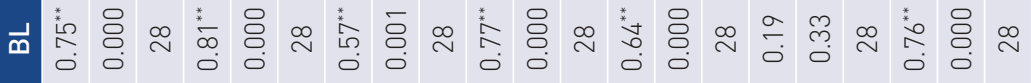

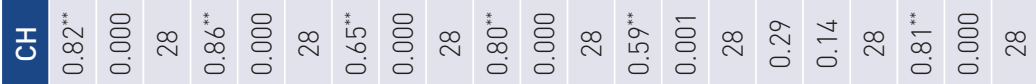

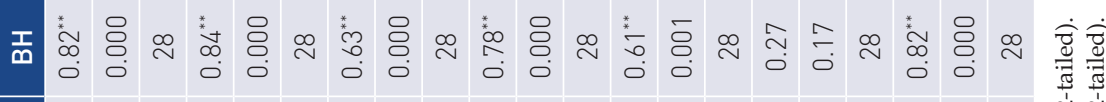

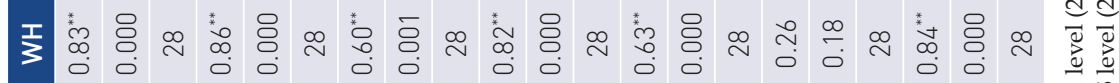

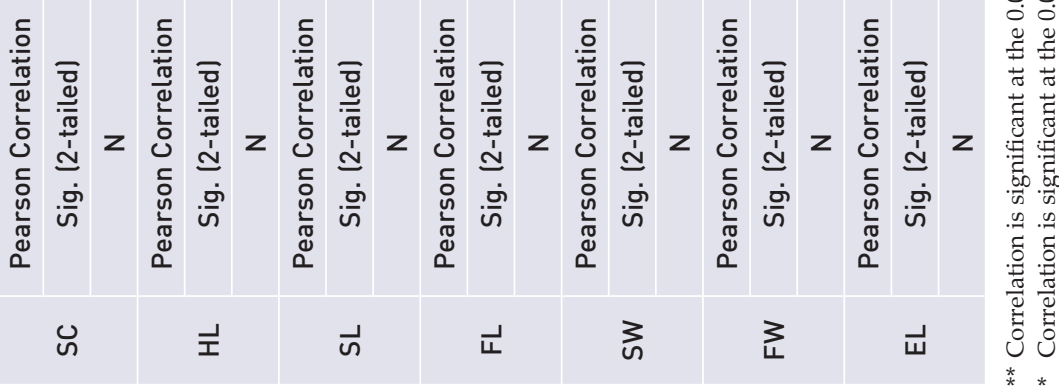




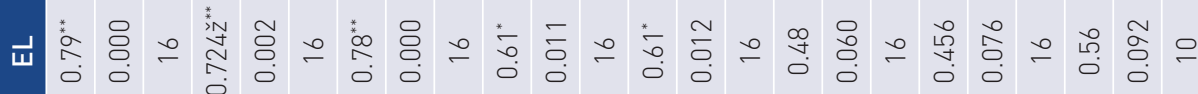

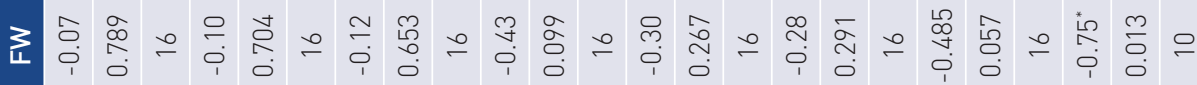

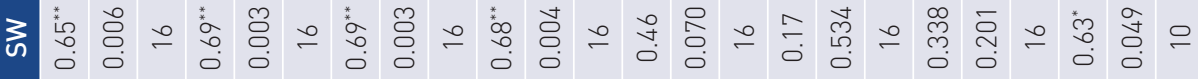

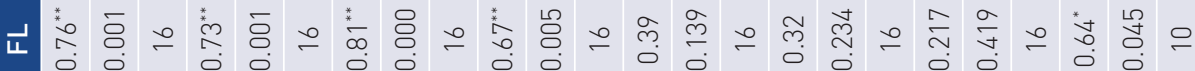

山苛总

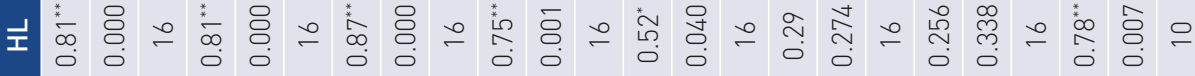

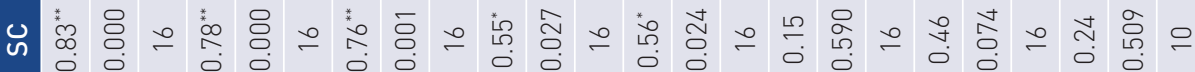

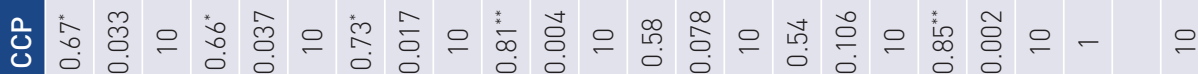

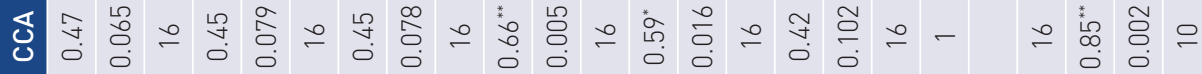

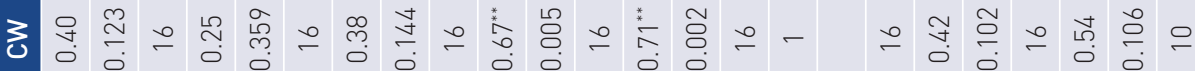

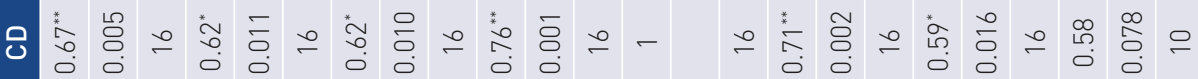

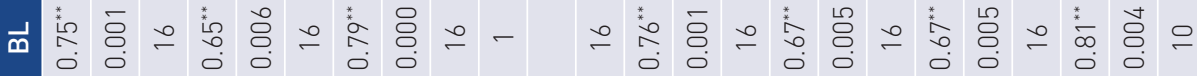

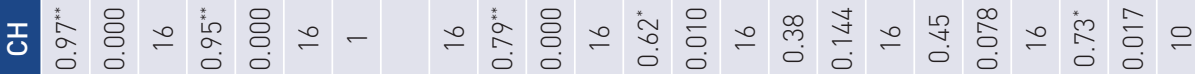

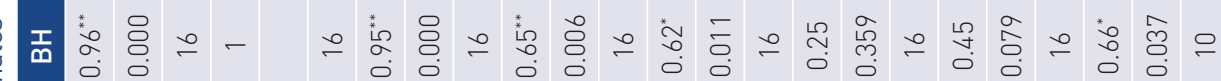
\&

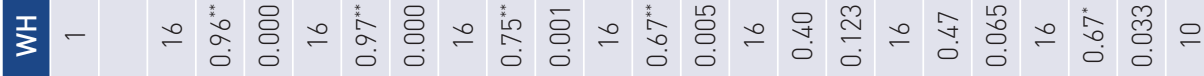

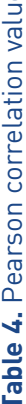

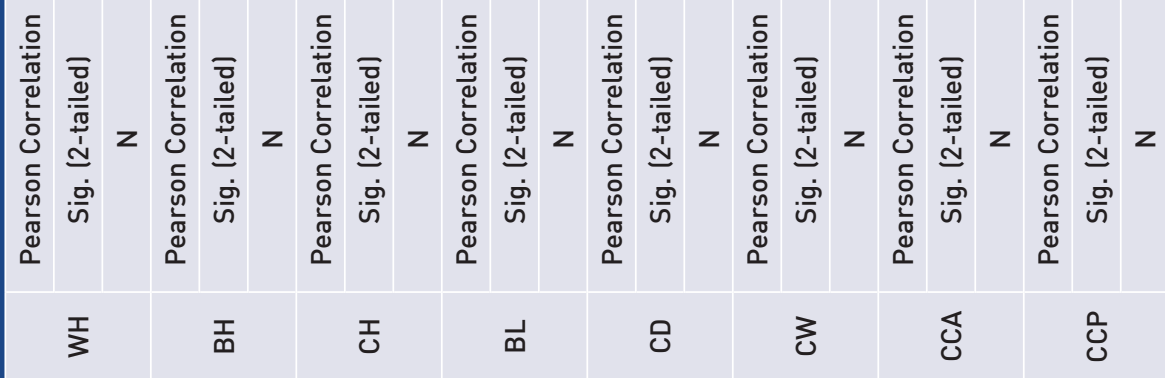




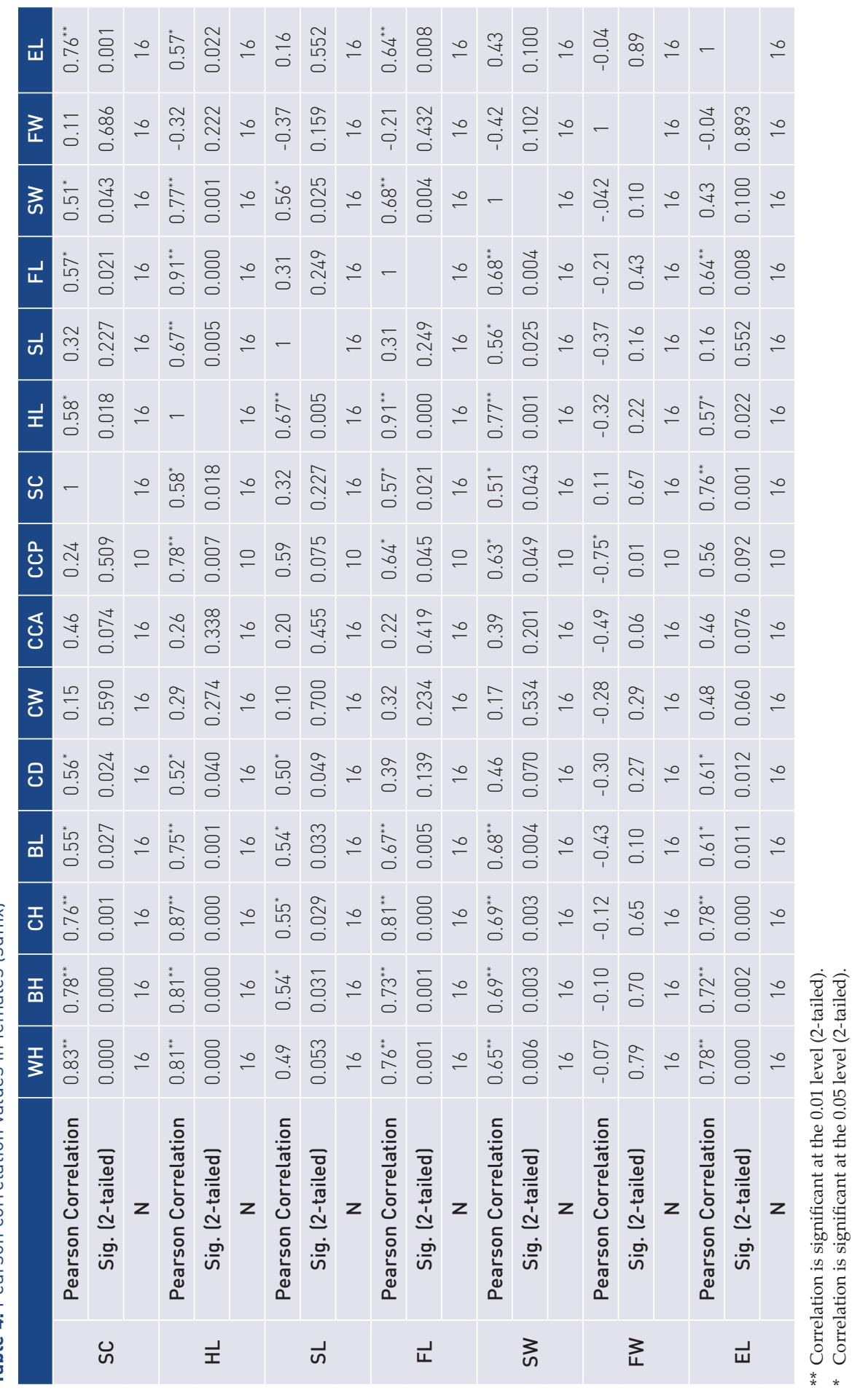




\section{Discussion}

Studying the basic morphological parameters of donkey Amiati in the Italian province of Tuscany, Orlandi et al. (1997) found that the average withers height of males was $135.5 \mathrm{~cm}$ and females $130.00 \mathrm{~cm}$. The height of the male donkey croup was, on average, $135.8 \mathrm{~cm}$ and the females $131.3 \mathrm{~cm}$. Regarding the height of the back, the average value in males was $132.6 \mathrm{~cm}$ and in females $126.8 \mathrm{~cm}$. The Romanesque breed is a large breed of Italian donkey in the big donkey group. The morphological characteristics of donkeys of this breed were studied by Beretti et al. (2005). The average height of the withers was $132.2 \mathrm{~cm}$ with a minimum of $117.0 \mathrm{~cm}$ and a maximum of $145.0 \mathrm{~cm}$. Chest circumference, on average, was $149.3 \mathrm{~cm}$. A rather wide variation interval from $119.0 \mathrm{~cm}$ to 178.0 $\mathrm{cm}$ was determined. Shin circumference had an average value of $17.0 \mathrm{~cm}$, minimum $14.0 \mathrm{~cm}$ and maximum 21.0 $\mathrm{cm}$. The big donkey group includes another Italian breed, Amiata. Casini et al. (2007) report that the average height of the withers of male Amiata donkeys is $125.82 \pm 5.25 \mathrm{~cm}$ and females 125.15 $\pm 5.21 \mathrm{~cm}$. Regarding the height of the croup, the average value for males was $129.80 \pm 26.30 \mathrm{~cm}$ and for females 129.89 $\pm 36 \mathrm{~cm}$. The circumference of the chest had an average value of $146.72 \pm 7.68 \mathrm{~cm}$ in male and $145.84 \pm 7.37 \mathrm{~cm}$ in females. The average body length of the males was $130.45 \pm 8.89 \mathrm{~cm}$ and females 128.62 $\pm 6.29 \mathrm{~cm}$. Regarding head length, the average value was found in males, 57.90 $\pm 2.81 \mathrm{~cm}$ and in females $55.82 \pm 2.42 \mathrm{~cm}$. The average value of the circumference of the shin in male was $17.40 \pm 0.70$ $\mathrm{cm}$ and in females $16.07 \pm 0.82 \mathrm{~cm}$. Compared to the sample of individuals in Austria, it is noticeable that the values of donkey parameters in Tuscany and other Italian breeds are larger than in Austria donkeys.
The morphological characteristics of donkeys in Turkey, the Igdir region, are reported by Yilmaz and Ertugrul (2011). The average height of the withers is $99.10 \mathrm{~cm}$. Average height of the withers of males was $99.70 \mathrm{~cm}$ and females 98.60 $\mathrm{cm}$, and average croup height was 102.30 $\mathrm{cm}$ in males and $100.90 \mathrm{~cm}$ in females, and $101.00 \mathrm{~cm}$ for the whole population. Body length, on average, was $103.00 \mathrm{~cm}$. In males, the average body length was $103.40 \mathrm{~cm}$ and in females $102.20 \mathrm{~cm}$. The chest circumference was, on average, $111.50 \mathrm{~cm}$. In males, this value averaged $112.80 \mathrm{~cm}$ and in females $111.60 \mathrm{~cm}$. The authors found that the average chest depth in the observed population was $45.40 \mathrm{~cm}$. The average chest depth of males was $45.60 \mathrm{~cm}$ and females 45.50 $\mathrm{cm}$. As for the chest width, a mean value of $29.10 \mathrm{~cm}$ was obtained. In males, the chest width had an average value of 29.40 $\mathrm{cm}$ and in females $28.70 \mathrm{~cm}$. The study showed that the average length of the head was $48.40 \mathrm{~cm}$. Males had an average head length of $48.80 \mathrm{~cm}$ and females $48.00 \mathrm{~cm}$. The total mean value of the shin circumference was $13.4 \mathrm{~cm}$, and in males $13.5 \mathrm{~cm}$ and females $13.10 \mathrm{~cm}$. Studying donkeys in western Turkey, Urosevic et al. (2016) found that the average height of the withers, in the observed population, in males was $104.2 \pm 3.7 \mathrm{~cm}$ with a minimum of $101.5 \mathrm{~cm}$ and a maximum of $108.5 \mathrm{~cm}$. In female, the average height of the withers was $103.1 \pm 2.2 \mathrm{~cm}$ with a range from 100.7 to $106.0 \mathrm{~cm}$. The same authors found that the average height of the donkey male in Northern Macedonia was $106.1 \pm 2.2$ with a range from 103.4 $\mathrm{cm}$ to $109.0 \mathrm{~cm}$. In females, the average height of the withers is $99.7 \pm 2.7 \mathrm{~cm}$ with a minimum of $96.0 \mathrm{~cm}$ and a maximum of $103.5 \mathrm{~cm}$. Studying donkeys in Romania, the same authors found that the average height of the withers in male was 100.8 in male $1.1 \mathrm{~cm}$, with a minimum height of $100.00 \mathrm{~cm}$ and a maximum of $101.6 \mathrm{~cm}$. In females, the average height of the withers 
was 101.2 in male $8.6 \mathrm{~cm}$ with an interval variation from $81.0 \mathrm{~cm}$ to $111.6 \mathrm{~cm}$. The population of donkeys in southern and southeastern Turkey was studied by Yilmaz and Trevor Wilson (2013). The average withers height of male was 102 $\pm 66 \mathrm{~cm}$ and females $99.7 \pm 0.58 \mathrm{~cm}$. The height of the back of males was $105.3 \pm$ $0.62 \mathrm{~cm}$ and females $102.4 \pm 0.56 \mathrm{~cm}$. The male body length was $105.2 \pm 0.74 \mathrm{~cm}$ and the females $103.1 \pm 0.65 \mathrm{~cm}$. As for the circumference of the chest, the authors found a mean value of $113.3 \pm 0.60 \mathrm{~cm}$ in males and $111.7 \pm 0.76 \mathrm{~cm}$ in females. Regarding head length, the average value was determined for male $49.0 \pm 0.27 \mathrm{~cm}$ and females $47.5 \pm 0.32 \mathrm{~cm}$. Regarding the volume of shin circumference, a mean value of $13.6 \pm 0.09 \mathrm{~cm}$ for males and 13.3 $\pm 0.10 \mathrm{~cm}$ for females was established. The values presented in this study show that both male and female donkeys in Austria are taller than donkeys in Turkey, and the mean croup height of males and females was higher than donkeys in Turkey. The average donkey body length in Austria is greater than of individuals measured in Turkey.

On the Adriatic islands, the donkey was a basic working animal. The morphological characteristics of donkeys on the island of Mljet were studied by Essert in 1959. The average donkey height was $100.65 \mathrm{~cm}$ and the donkey $99.48 \mathrm{~cm}$, with a total mean of $100.23 \mathrm{~cm}$. Regarding back height, the average was $102.77 \mathrm{~cm}$, while in males, the average height of the back was $102.95 \mathrm{~cm}$ and in females 102.26 $\mathrm{cm}$. Average croup height was $103.37 \mathrm{~cm}$, with averaged croup height of $102.86 \mathrm{~cm}$ in males and $103.26 \mathrm{~cm}$ in females. The total average body length was $100.81 \mathrm{~cm}$. In males, this value was $100.11 \mathrm{~cm}$ and in females $100.93 \mathrm{~cm}$. Chest circumference, on average, was $107.82 \mathrm{~cm}$ for males and $108.80 \mathrm{~cm}$ for females with a total average value of $108.83 \mathrm{~cm}$. The mean value of the circumference of the shin was 12.23 $\mathrm{cm}$ with $12.60 \mathrm{~cm}$ in male and $12.16 \mathrm{~cm}$ in female individuals. The population of donkeys in the Adriatic islands is shorter than donkeys in Austria. Also interesting is the donkey body size on the Adriatic islands, which is square, while the population in Austria has a rectangular body format.

In the first study on the baroque donkey, Urosevic et al. (2019) report that the average withers height of males is $115.5 \mathrm{~cm}$ with a range from $108.4 \mathrm{~cm}$ to $120.3 \mathrm{~cm}$. In females, the average height of the withers is $112.2 \mathrm{~cm}$ with a range from $104.2 \mathrm{~cm}$ to $122.2 \mathrm{~cm}$. The average back height of females is $109.3 \mathrm{~cm}$ with a range from $102.0 \mathrm{~cm}$ to $118.7 \mathrm{~cm}$. In males, the average back height is 112.8 $\mathrm{cm}$ with a minimum value of $102.1 \mathrm{~cm}$ and a maximum of $119.1 \mathrm{~cm}$. The height of the croup, on average, in males was $118.3 \mathrm{~cm}$ and with an interval of variation from $111.1 \mathrm{~cm}$ to $125.1 \mathrm{~cm}$. In females, the average croup height is $115.0 \mathrm{~cm}$ with a minimum of $108.2 \mathrm{~cm}$ and a maximum of $126.5 \mathrm{~cm}$. Average female body length is $120.7 \mathrm{~cm}$ with a minimum of $108.9 \mathrm{~cm}$ and a maximum of $133.0 \mathrm{~cm}$. In males, the average body length is $119.2 \mathrm{~cm}$, the minimum is $112.0 \mathrm{~cm}$ and the maximum is $127.0 \mathrm{~cm}$. Average chest depth of males is $49.2 \mathrm{~cm}$, minimum $48.0 \mathrm{~cm}$ and maximum $52.0 \mathrm{~cm}$. In females, the chest had an average depth of $52.2 \mathrm{~cm}$, the minimum was $48.0 \mathrm{~cm}$ and the maximum was 55.0 $\mathrm{cm}$. The average anterior circumference of the chest of females is $124.5 \mathrm{~cm}$ with an interval of $110.0 \mathrm{~cm}$ to $135.0 \mathrm{~cm}$. In males, the mean value for this parameter was $118.6 \mathrm{~cm}$ with a minimum of 110.0 $\mathrm{cm}$ and maximum $130.0 \mathrm{~cm}$. The average head length in males was $55.0 \mathrm{~cm}$ with a skull length of $24.8 \mathrm{~cm}$. In females, the average head length is $54.5 \mathrm{~cm}$ and skull length of the skull is $25.0 \mathrm{~cm}$. The females, on average, had a shin circumference of $13.0 \mathrm{~cm}$ with an interval of variation from $12.9 \mathrm{~cm}$ to $14.0 \mathrm{~cm}$. In males, the average value of the circumference of the shin is $14.0 \mathrm{~cm}$ with an interval of $13.0 \mathrm{~cm}$ to 
$16.0 \mathrm{~cm}$. The studied donkey population presented here has similar values, with smaller oscillations in some parameters, as Baroque donkeys. However, the variation intervals are higher in this population than in the Baroque donkey. Approximately the same parameter values can be explained that both populations share the same distribution range of origin and where they live today. In the Baroque donkey, the variation intervals are likely to be smaller due to controlled breeding and more stringent criteria for breeding individuals over the last few centuries.

The external characteristics of donkeys in the Kabylie area of Algeria are reported by Ayad et al. (2019). They found that the average withers height of individuals younger than 5 years was $106 \pm 6.3 \mathrm{~cm}$. The average height of the withers was $105.3 \pm 4.8 \mathrm{~cm}$, in individuals from 6 to 10 years old, and $103.2 \pm 5.2$ $\mathrm{cm}$ in those older than 11 years. The height of the croup, on average, in young individuals was $110.2 \pm 5.8 \mathrm{~cm}$, in adults $108.7 \pm 5.3 \mathrm{~cm}$ and over the age of 11 years $107.2 \pm 3.7 \mathrm{~cm}$. When it comes to body length, the authors found that the average body length of the young individuals was $107.3 \pm 8.7 \mathrm{~cm}$, in adults up to 10 years of age, the body length averaged $109.6 \pm$ $3.5 \mathrm{~cm}$ and $108.4 \pm 6.4 \mathrm{~cm}$ in those older than 11 years. Circumference of the shin, the average value in young individuals was $14.5 \pm 1.3 \mathrm{~cm}$, in those between 6 and 10 years $14.8 \pm 0.6$ and for individuals older than 11 years this value was $14.7 \pm$ $0.9 \mathrm{~cm}$. Algerian donkeys have a slightly lower withers height than the studied population in Austria.

Ebangi and Vall (2005) reported the basic morphological parameters of donkeys in the Sudan-Sahel region of Cameroon. The average height of the withers is $98.05 \mathrm{~cm}$ with a range of 90.00 to $110.00 \mathrm{~cm}$. The average body length was $137.26 \mathrm{~cm}$ with a minimum value of $115.00 \mathrm{~cm}$ and a maximum of $173.00 \mathrm{~cm}$.
The circumference of the chest, measured behind the elbow joint, is $107.53 \mathrm{~cm}$ with an interval of variation from 97.00 to $125.00 \mathrm{~cm}$. This donkey population is significantly shorter than the population in Austria. The size of the donkey body in Cameroon is very interesting as it is very rectangular. The body length and body size of the donkey population in Cameroon is significantly higher than the population in Austria.

Tsega and Lemma (2015) studied the bodily form of donkeys in northwestern and central Ethiopia, where the largest donkeys in Ethiopia are found. For working individuals, the average height of the withers was $118 \pm 5.54 \mathrm{~cm}$ with an interval of variation from 102.00 to 140.00 $\mathrm{cm}$. The chest circumference averaged $124.4 \pm 2.2 \mathrm{~cm}$ with variations from 103.00 to $156.00 \mathrm{~cm}$. Ethiopia's population is slightly taller than donkeys in Austria.

Ivankovic et al. (2000) reported that in the Littoral Dinaric donkey, the average height of the withers was $96.93 \mathrm{~cm}$, the circumference of the chest was $112.75 \mathrm{~cm}$ and the circumference of the shin was $12.82 \mathrm{~cm}$. In the North Adriatic donkey, the average height of the withers is $115.28 \mathrm{~cm}$, the circumference of the chest is $131.80 \mathrm{~cm}$ and the circumference of the shin is $14.85 \mathrm{~cm}$. The Istrian donkey has an average ridge height of 124.07 $\mathrm{cm}$, a chest circumference of $144.01 \mathrm{~cm}$ and a shin circumference of $16.30 \mathrm{~cm}$. The average croup height for the Littoral Dinaric donkey is $99.85 \mathrm{~cm}$, for the North Adriatic donkey $119.21 \mathrm{~cm}$ and for the Istrian donkey $128.29 \mathrm{~cm}$. The average body length of the Littoral Dinaric donkey is $102.62 \mathrm{~cm}$, in the North Adriatic 121.11 $\mathrm{cm}$ and in the Istrian Donkey $131.30 \mathrm{~cm}$. The population of donkeys in Austria is most similar to the northern donkey in terms of parameters.

The morphometric characteristics of donkeys in northwestern Nigeria were examined by John et al. (2017). In the observed population, average head length 
was $39.9 \mathrm{~cm}$, average chest circumference was $94.3 \mathrm{~cm}$, and body length $92.0 \mathrm{~cm}$. The average height of the withers is 92.8 $\mathrm{cm}$. Compared to this study, donkeys in Austria are significantly taller.

The Catalan donkey also belongs to the group of tall donkeys. Polch and Jordana (1997) reported that the average height of males is $142.20 \mathrm{~cm}$ with an interval of variation from $129.0 \mathrm{~cm}$ to $156.0 \mathrm{~cm}$. In females, the average height of the withers is $136.29 \mathrm{~cm}$, a minimum of $123.0 \mathrm{~cm}$ and a maximum of $148.0 \mathrm{~cm}$. The average back height of males was $137.44 \mathrm{~cm}$ with a minimum of $126.0 \mathrm{~cm}$ and a maximum of $152.0 \mathrm{~cm}$. The average back height of females is $132.68 \mathrm{~cm}$ with a minimum value of $120.0 \mathrm{~cm}$ and a maximum of $144.0 \mathrm{~cm}$. Males have an average croup height of $143.0 \mathrm{~cm}$ with a range from 127.0 to $157.0 \mathrm{~cm}$. In females this average value is $139.59 \mathrm{~cm}$ with a range from $127.0 \mathrm{~cm}$ to $150.0 \mathrm{~cm}$. Chest circumference, on average, in males was $157.00 \mathrm{~cm}$ with a minimum value of $146.0 \mathrm{~cm}$ and a maximum of $170.0 \mathrm{~cm}$. In female, the average chest circumference is $154.70 \mathrm{~cm}$ with an interval from 140.0 $\mathrm{cm}$ to $169.0 \mathrm{~cm}$. When it comes to the head, the authors determined that males, on average, have a head $61.24 \mathrm{~cm}$ long, with a minimum length of $55.0 \mathrm{~cm}$ and a maximum of $68.0 \mathrm{~cm}$. Comparing the values obtained in our study, the population in Austria has lower values in all parameters compared to Catalan donkeys.

Đermanović et al. (2013) studied the morphometry of young donkeys, up to two years old, in the area of southern Serbia. They determined that the average height at the withers of females was 100.5 $\mathrm{cm}$, body length was $101.30 \mathrm{~cm}$, chest circumference was $105.45 \mathrm{~cm}$, and shin circumference was $11.80 \mathrm{~cm}$. In males, the average value of the height at the withers was $100.27 \mathrm{~cm}$, body length was 101.27 $\mathrm{cm}$, chest circumference was $105.64 \mathrm{~cm}$, and shin circumference was $11.82 \mathrm{~cm}$.
Studying the exterior traits of domestic donkey in southeastern Serbia, Trailović et al. (2011) found that the average height at the withers is $105.72 \mathrm{~cm}$, body length $112.06 \mathrm{~cm}$, chest circumference 114.44 $\mathrm{cm}$ and shin circumference $12.67 \mathrm{~cm}$. The population of donkeys in Southern Serbia is significantly shorter and with a shorter body compared to the population in Austria.

When it comes to the morphological characteristics of donkeys in Bulgaria, extensive research was done by Vlaeva et al. (2016). Studying donkeys in three regions in Bulgaria, the authors found that the average withers height was $119.80 \pm 8.09 \mathrm{~cm}$ with an interval of variation from $99.0 \mathrm{~cm}$ to $148.0 \mathrm{~cm}$. The average body length was $124.64 \pm 9.28$ $\mathrm{cm}$ with a minimum value of $102.0 \mathrm{~cm}$ and a maximum of $154.0 \mathrm{~cm}$. Chest circumference had an average value of $136.69 \pm 9.94 \mathrm{~cm}$ with a minimum of $115.0 \mathrm{~cm}$ and a maximum of $160.0 \mathrm{~cm}$. The donkeys of these populations are quite strong, since the average shin circumference is $16.01 \pm 1.35 \mathrm{~cm}$, with a minimum of $13.0 \mathrm{~cm}$ and maximum of $20.0 \mathrm{~cm}$. The donkey population in Bulgaria is larger and stronger in relation to the population in Austria.

The connection between head length and the withers height was studied in Romania, Northern Macedonia and Turkey by Urošević et al. (2015). The minimum head length for females in Romania was $44.0 \mathrm{~cm}$ and the maximum $54.0 \mathrm{~cm}$. The average value was $49.1 \mathrm{~cm}$. In Northern Macedonia, the minimum head length of females was $48.0 \mathrm{~cm}$ and a maximum of $56.0 \mathrm{~cm}$ was determined, and the average head length of female donkeys was $50.4 \mathrm{~cm}$. When it comes to Turkey, the minimum value of the length of the head was $48.0 \mathrm{~cm}$ with a maximum of $51.0 \mathrm{~cm}$, and the average value was 50.0 $\mathrm{cm}$. No statistically significant differences in head length were observed within the observed groups. In the donkey 
population in Austria, the average head length is almost the same as the average head length in individuals in the populations in these three countries.

The morphological characteristics of donkeys in the Czech Republic are reported by Kostukova et al. (2015). Considerable variability was found in the height of the withers. The minimum value of withers height was $98.0 \mathrm{~cm}$, and the maximum was $131.0 \mathrm{~cm}$. the average value was $107.5 \mathrm{~cm}$. The average back height was $105.5 \mathrm{~cm}$, with a minimum value of $91.5 \mathrm{~cm}$ and a maximum of 130.0 $\mathrm{cm}$. For croup height, the average value was $110.7 \mathrm{~cm}$, the minimum $95.0 \mathrm{~cm}$, and the maximum value of the height of the croup $139.0 \mathrm{~cm}$. Donkeys in the observed population had an average head length of $44.4 \mathrm{~cm}$, minimum head length of $37.5 \mathrm{~cm}$ and maximum of 54.0 $\mathrm{cm}$. Chest circumference averaged 129.5 $\mathrm{cm}$ with a range from $111.0 \mathrm{~cm}$ to 155.0 $\mathrm{cm}$. The studied population in Austria has a similar interval of variation while the average value is significantly higher.

The morphological characteristics of the Hasavi donkeys, an indigenous breed of donkeys in the eastern province of Saudi Arabia were reported by the Shawaf et al. (2016). The donkeys of this race belong to the group of large donkeys. The average height of the males is $130.5 \pm 1.3 \mathrm{~cm}$ and females $126.3 \pm 1.1$ $\mathrm{cm}$. When it comes to back height, the average height was $127.2 \pm 1.2 \mathrm{~cm}$ for of males, and $123.3 \pm 1.1 \mathrm{~cm}$ for females. Croup height was greater than the height of the withers, and was $133.8 \pm 1.1 \mathrm{~cm}$ in males and $129.4 \pm 1.0 \mathrm{~cm}$ in females. The average body length for males was 185.8 $\pm 2.8 \mathrm{~cm}$ and $178.8 \pm 1.3 \mathrm{~cm}$ for females. Shin circumference in males was 16.8 $\pm 0.4 \mathrm{~cm}$ and in females $15.5 \pm 0.2 \mathrm{~cm}$. Donkeys of this breed have significantly higher parameter values in relation to the studied population in Austria.

Considering the three donkey populations in Turkey, Northern
Macedonia and Romania, Urošević et al. (2019) found that donkeys in this region are smaller in size. Average withers height of males was $104.9 \pm 3.1 \mathrm{~cm}$ with a minimum value of $100.0 \mathrm{~cm}$ and a maximum of $109.0 \mathrm{~cm}$. In females, the average height of the withers was 101.5 $\pm 3.9 \mathrm{~cm}$ with a minimum of $95.1 \mathrm{~cm}$ and a maximum of $107.5 \mathrm{~cm}$. Average back height of males is $102.8 \pm 3.5 \mathrm{~cm}$, minimum $97.4 \mathrm{~cm}$ and maximum 108.0 $\mathrm{cm}$. In females, the backs are on average $99.3 \pm 3.1 \mathrm{~cm}$ high. The minimum is 94.5 $\mathrm{cm}$ and the maximum $104.3 \mathrm{~cm}$. Average croup height was $106.6 \pm 3.2 \mathrm{~cm}$ in males with a minimum value of $102.3 \mathrm{~cm}$ and a maximum value of $114.5 \mathrm{~cm}$. In females, croup height was on average $105.7 \pm 3.5$ $\mathrm{cm}$ with a range from $100.3 \mathrm{~cm}$ to 112.1 $\mathrm{cm}$. In males, body length ranged from $97.0 \mathrm{~cm}$ to $123.0 \mathrm{~cm}$ with an average value of $113.4 \pm 7.2 \mathrm{~cm}$. Females had an average body length of $113.6 \pm 10.5 \mathrm{~cm}$ with a range of $100.0 \mathrm{~cm}$ to $138.0 \mathrm{~cm}$. These observed populations in three different countries had lower values than the studied donkey population in Austria.

\section{Conclusions}

In relation to the sample of individuals of the population in Austria, it is noticeable that the values of the stated parameters of donkeys in Tuscany and other Italian breeds are higher in relation to the same parameters of donkeys in Austria. The values obtained in our study show that donkeys in Austria, both males and females, are taller than donkeys in Turkey, with a higher croup height. The average body length of donkeys in Austria is greater than the body length of individuals measured in Turkey. The body shape of donkeys on the Adriatic islands is square, while the population in Austria has a rectangular body shape. The body length and body size of the donkey population in Cameroon is 
significantly larger than the population in Austria. The observed populations in three different countries had lower values compared to the studied donkey population in Austria.

The Pearson correlation showed a very significant or significant positive statistical correlation between almost all parameters in males. No statistically significant correlation was observed between the skull width and height at the withers, height of the back, croup height, body length, chest depth, anterior circumference of the chest, skull length, or length of the ears. In females, Pearson correlation values had slightly different values than males. There was no statistically significant correlation between chest width and anterior chest circumference with almost all other parameters. In females, a negative correlation was observed between the width of the cranial part and all other parameters.

\section{References}

1. AYAD, A., S. AISSANOU, K. AMIS, A. LATRECHE and M. IGUER-OUADA (2019): Morphological Characteristics of Donkeys (Equus asinus) in Kabylie area, Algeria. Slovak J. Anim. Sci. 52, 53-62.

2. IVANKOVIĆ, A., P. CAPUT, B. MIOČ i V. PAVIĆ (2000): Fenotipske značajke magaraca u Hrvatskoj. Agric. Conspect. Sci. 65, 99-105.

3. TSEGA, A. and A. LEMMA (2015): Phenotypic characteristics and sexual behavior of Sennar Jacks (Equus asinus). Ethiop. Vet. J. 19, 11-21.

4. BERETTI, V., A. ZANON, C. S. SOFFIANTINI and A. SABBIONI (2005): Preliminary Results about Morphological and Demographic traits of Romagnolo Donkey. Ann. Fac. Medic. Vet. di Parma XXV, 131-144.

5. ĐERMANOVIĆ, V., S. MITROVIĆ, S. IVANOV, M. NOVAKOVIĆ i G. STANIŠIĆ (2013): Varijabilnost telesnih mera omadi balkanskog magarca gajenog u južnoj Srbiji. Radovi XXVI savetovanja agronoma, veterinara, tehnologa i agroekonomista 18, 139-145.

6. ESSERT, Z. (1959): Domaći magarac otoka Mljeta. Veterinaria, 1, 41-54

7. EBANGI, L. A. and E. VALL (2005): Dry Season Effect on Live Weight and some Body Dimensions of Working Donkeys in the Sudano-sahel Region of Cameroon. Tropicultura 23, 48-52.
8. FOLCH, P. and J. JORDANA (1997): Characterization, reference ranges and the Influence of Gender on Morphological Parameters of the Endangered Catalonian donkey Breed. J. Eq. Vet. Sci. 17, 102-111.

9. JOHN, A. P., G. N. AKPA and A. O. IYIOLATUNJI (2017): Characterization of weaner donkeys in northwest Nigeria using morphometric traits. Niger. J. Anim. Prod. 19, 36-49.

10. CASINI, L. M. SGORBINI, L. MAGNI and M. CORAZZA (2007): Valutazioni Morfologiche nellAsino Sorcino crociato dellAmiata. Ippologia 18, 33-35.

11. ORLANDI, M., M. C. CURADI, R. LEOTTA, R. IMPEDUGLIA and R. BENEDETTI (1997): Morphophysiological characterization of Amiatan donkey. Stočarstvo 51, 443-447.

12. KOSTUKOVA, M., H. ČERNOHORSKA, I. BIHUNCOVA, I. ORACOVA, E. SOBOTKOVA and I. JISKROVA (2015): Characteristics of Morphological Parameters of Donkeys in the Czeh Republic. Acta Univ. Agric. et Silvic. Mendelianae Brunensis 63, 419-424

13. UROŠEVIĆ, M., M. NEMECEK, D. DROBNJAK, M. B. UROŠEVIĆ, D. MATARUGIĆ and P. STOJIĆ (2015): Head Length and Pelvis Length Ratio on Relation to the Height of Withers in Donkey Female. Agro-knowledge J. 16, 637-643.

14. UROŠEVIĆ, M., M. NEMECEK, D. DROBNJAK, P STOJIĆ, N. PRAČIĆ and D. MATARUGIĆ (2016): Length of Ears of Domestic Donkey (Equus Asinus) in Relation to Heigth at Withers. Radovi s XXX savetovanja agronoma, veterinara, tehnologa i agroekonomista 22, 95-98.

15. UROŠEVIĆ, M., M, NEMECEK, D. DROBNJAK and P. STOJIĆ (2019): Morphometric parameters body in donkey. Vet. stn. 50, 133-136.

16. UROSEVIC, M., M. NEMECEK, D. DROBNJAK, A. GANGL, P. DAMESKI, P. STOJIĆ and G. STANISIC (2019): Morphological Characterization of the White Baroque Donkey. Animal Health, Prod. Hyg. 8, 627-633.

17. YILMAZ, O. and M. ERTUGRUL (2011): Some Morphological Traits of Donkeys Raised in Igdir, Turkey. Igdir Univ. J. Inst. Sci \& Tech 1, 113-116.

18. YILMAZ, O. and R. TREVOR WILSON (2013): The domestic Livestock resources of Turkey: Notes on Donkeys. J. Anim. Plant Sci. 23, 651-656.

19. VLAEVA, R., S. GEORGIEVA, G. NARZEV and I. IVANOVA (2016): Morphological and Phenotypic characteristics of Donkeys in some regions of Bulgaria. Trakia J. Sci. 1, 92-95.

20. TRAILOVIĆ, R., S. IVANOV, V. DIMITRIJEVIĆ and D. TRAILOVIĆ (2011): Morphological and Health Characteristics of domestic Balkan Donkey on Stara planina.Equine Nutrition and Pathology. Horseville, Proceedings, pp. 180-187.

21. SHAWAF, T., F. ALMATHEN, J. AL-AHMAD and A. ELMOSLEMANY (2016): Morphological Characteristics of Hassawi Donkey, Eastern Province, Saudi Arabia. Alex. J. Vet. Sci. 49, 178-183. 


\section{Povezanost morfoloških parametara magaradi u Austriji}

Dr. agr. sc. Milivoje UROŠEVIĆ, dr. med. vet. spec., mr. sc. Darko DROBNJAK, dr. med. vet., COAR - Centar za očuvanje autohtonih rasa Beograd, Srbija; dr. agr. sc. Radka VLAEVA, Predstojnica katedre za kopitare, Poljoprivredni fakultet Univerziteta u Staroj Zagori, Bugarska; dr. agr. sc. Goran STANIŠIĆ, profesor, dipl. inž, polj., Viša poljoprivredna škola, Šabac, Srbija; dr. sc. Radomir MANDIĆ, docent, Fakultet za primenjenu ekologiju, Univerzitet Metropolitan, Beograd, Srbija; mr. sc. Natalija GRITTNER, COAR - centar za očuvanje autohtonih rasa Beograd, Srbija; dr. sc. Panče DAMESKI, docent, dr. med. vet., Fakultet veterinarske medicine, Univerzitet "Sv. Kliment Ohridski", Bitola, Sjeverna Makedonija

Posljednjih desetljeća polako, ali stalno, magarac gubi mjesto kao svugdje prisutna radna snaga. Industrijalizacija poljoprivrede, mehanizacija mnogih poslova $\mathrm{u}$ brdskim i planinskim predjelima prouzročili su smanjenje broja magaradi. Intenzitet smanjenja prešao je granicu alarmantnosti. Da bi se uspješno vodila akcija revitalizacije magaradi u njihovim uobičajenim, a i novim arealima neophodno je ovu domaću životinju upoznati s različitih aspekata. $U$ tom je smislu obavljeno i ovo istraživanje. Domaći magarac (Equus asinus) potječe iz Afrike. Razlikuju se nubijski i somalijski magarci. Poznata je velika radna izdržljivost magaradi, koja je pomalo i mistična. Ne postoje geografski predjeli gdje magarad ne obavljaju najteže oblike rada, prije svega transporta. Za svako čuđenje je njihova mogućnost kretanja i stabilnost po nepristupačnim terenima. Za potrebe ovog rada korištena je ukupno 44 magaradi (28 mužjaka i 16 ženki). Proučavane jedinke su s područja Republike Austrije. Analizirani su sljedeći morfometrijski parametri: visina grebena, visina leđa, visina križa, dužina trupa, dubina prsa, širina prsa, obujam prsa prednji, obujam prsa zadnji, obujam cjevanice, dužina glave, dužina lubanje, dužina facijalnog dijela, širina lubanje, širina facijalnog dijela, dužina ušiju. Mjerenje je obavljeno pomoću Litinovog štapa, pantljike i pomičnog mjerila s nonijusem. Prosječna visina grebena iznosila je $116,40 \mathrm{~cm}$, a interval variranja od $99,60 \mathrm{~cm}$ do $140,60 \mathrm{~cm}$. Visina grebena ženki varira od $90.50 \mathrm{~cm}$ do $125.70 \mathrm{~cm}$. U prosjeku ženke su visoke 102,38 $\mathrm{cm}$ sa standardnom devijacijom od 8,28 i standardnom grješkom od 2,07. Dužina trupa u mužjaka u prosjeku je iznosila $121,85 \mathrm{~cm}$ sa standardnom devijacijom od 11,79. Dužina trupa ženki iznosila je od 101,00 cm do 131,00 $\mathrm{cm}$. Srednja vrijednost dužine trupa u ženki bila je $115,80 \mathrm{~cm}$. Dužina glave mužjaka bila je od 48,00 do $71,00 \mathrm{~cm}$, s prosječnom vrjednošću od $55,60 \mathrm{~cm}$. Dužina glave u ženskih jedinki varira od 43,00 do $56,00 \mathrm{~cm}$. Glava je prosječno bila duga $50,06 \mathrm{~cm}$ sa standardnom devijacijom od 3,23. Primjenom Personove korelacije zabilježena je vrlo značajna ili značajna pozitivna statistička korelacija između gotovo svih parametara u mužjaka. U ženki vrijednosti Personove korelacije imaju nešto drugačije vrijednosti nego u mužjaka. Između širine prsa i prednjeg obujma prsa nije bilo statistički značajne korelacije $\mathrm{s}$ gotovo svim ostalim parametrima. Za ove parametre jedino je pozitivna vrlo značajna statistička korelacija zabilježena između dužine trupa i širine prsa, kao i prednjeg obujma prsa; zatim između prednjeg i zadnjeg obujma prsa i dubine prsa ova dva parametra. U ženki je zabilježena i negativna korelacija između širine lubanjskog dijela i svih ostalih parametra.

Ključne riječi: magarac, morfometrija, korelacija 